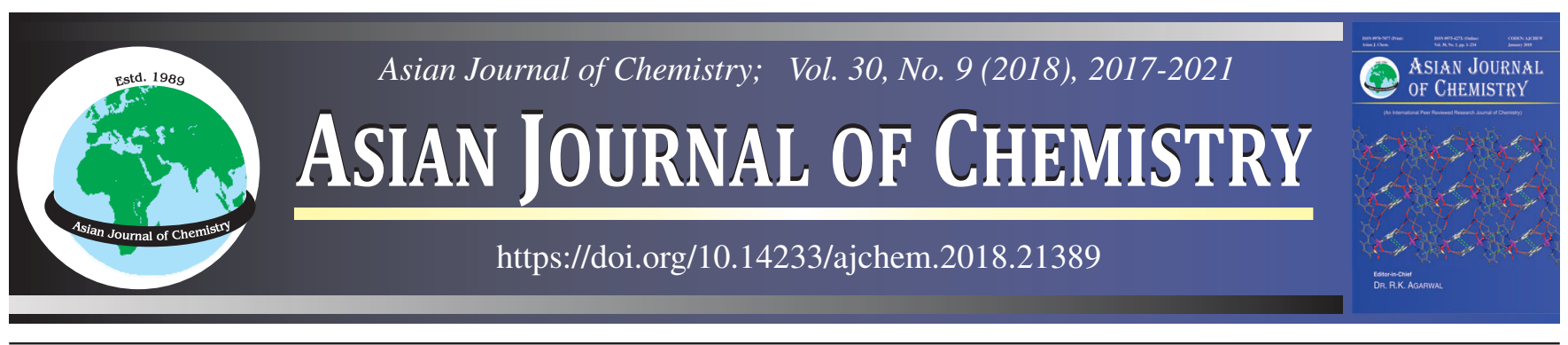

\title{
Synthesis and Spectroscopic Study of Some Transition Metal Complexes with New Pyrazolinone Ligand Derived from 2-Hydrazino Quinoxaline-3-one
}

\author{
Mahmoud NaJim Al-Jibouri", TAghreed M. Musa and Ahmad H. Ismail
}

Department of Chemistry, College of Science, Mustansiriyah University, Baghdad, Iraq

*Corresponding author: E-mail: mahmoud_inor71@uomustansiriyah.edu.iq; mahmoudnajim71@yahoo.com

Received: 14 April 2018;

Accepted: 17 July 2018;

Published online: 31 July 2018;

AJC-19013

New transition metal complexes of manganese(II), cobalt(II), nickel(II), copper(II) and zinc(II) with (E)-3-[4-(hydroxy(phenyl)methylene)3-methyl-5-oxo-4,5-dihydro-1H-pyrazol-1-yl]quinoxalin-2(1H)one were synthesized and characterized by elemental analysis, FT-IR, NMR and mass spectra. The ligand was synthesized by the reaction of 2-hydrazinoquinoxaline-3(1H,4H)-one with 3-acetylcoumarin. All the metal complexes are found to be monomer in nature and have tetrahedral geometry. The IR spectra data revealed that the ligand behaves as neutral bidentate Lewis base through two nitrogen atoms of pyrazole and pyrazine moiety forming six-membered ring. The molar conductivity measurements suggested the neutral nature of all metal complexes in DMF solution. The magnetic moment measurements investigated the high spin properties of all the metal complexes.

Keywords: Transition metal(II) complexes, Pyrazole, Pyrazolinone.

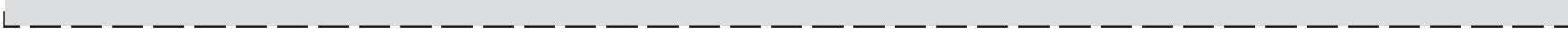

\section{INTRODUCTION}

The five membered nitrogen-containing heterocyclic compounds as pyrazolines have shown important antitumor, antitrypanosomal [1,2] and antileishmanial activity [3]. Pyrazole and coumarin derivatives are the ligand in chemical and biological systems as it appears as such in proteins, and together with its derivatives, has been extensively employed for modeling in a wide range of inorganic subject areas, from biological applications to electronic devices and materials [4].

Budzisz et al. [5] reported the anticancer activity of copper(II), palladium(II) and platinum(II) complexes derived from bidentate pyrazoline ligands. Furthermore, the investigation of transition metal complexes with 1,3,5-pyrazole ligands have interested wide ranges in bio-inorganic chemistry [6-8]. Over the years, the coordination chemistry of pyrazoline has received considerable attention [6-8]. The DNA-cleavage of copper(II) complexes with mixed ligands involving pyrazoline moiety have assigned the high significances of pyrazoline complexes in the pharmaceutical industry [9]. The transition metals complexes of their quinoxaline-2-one have interested great attention due to their potential metal binding characteristics and promising extreme applications [10-12]. The complexes of cadmium(II) with di-sigma pyrazoles have studied with X-ray crystallography $[13,14]$. In view of the importance of such quinoxaline and pyrazoles ligands, we report here the synthesis and characterization of pyrazoline-quinoxaline based ligand and its manganese(II), cobalt(II), nickel(II), copper(II) and zinc(II) metal ion complexes. The structure of $(E)$-3-[4(2-hydroxybenzylidene)-3-methyl-5-oxo-4,5-dihydro-pyrazol1-yl]-1 $H$-quinoxalin-2-one and its metal complexes have elucidated by NMR, FT-IR, mass spectra and elemental analyses.

\section{EXPERIMENTAL}

Elemental analyses (CHNS) of ligand and its metal(II) complexes were determined using Carlo-Erba 1106 Elemental analyzer and Perkin-Elmer CHNS240 elemental analyzer. The electronic spectra were recorded using Shimadzu spectrometer in the range $200-800 \mathrm{~nm}$ in DMF solvent. The ${ }^{1} \mathrm{H}$ and ${ }^{13} \mathrm{C}$ NMR spectra were carried at Al-Yarmook University, Jordan on Bruker $400 \mathrm{MHz}$ spectrometer in DMSO- $d_{6}$ solvent. The Fourier transform infrared spectra of the prepared complexes were recorded in $\mathrm{KBr}$ and CsI discs on Shimadzu model FT-IR8400 spectrometer at Laboratory of Chemistry Department, College of Science, university of Mustansiryah, Baghdad, Iraq. The molar conduc-

This is an open access journal, and articles are distributed under the terms of the Creative Commons Attribution-NonCommercial 4.0 International (CC BY-NC 4.0) License, which allows others to copy and redistribute the material in any medium or format, remix, transform, and build upon the material, as long as appropriate credit is given and the new creations are licensed under the identical terms. 
tance measurements were made on Hanna conductivity meter with a cell constant of $1.0 \mathrm{~cm}^{-1}$. The atomic absorption measurements were performed using the Analytik Jena /A Spect LSFL 1.3.0.0, Ibn Sina Center, Ministry of Industry, Iraq.

All the reagents and solvents used were of laboratory grade. The synthesis of new ligand was monitored by TLC using silica gel-G plates (Ranbaxy) for TLC. The hydrated metal chlorides $\mathrm{MnCl}_{2} \cdot 4 \mathrm{H}_{2} \mathrm{O}, \mathrm{CoCl}_{2} \cdot 6 \mathrm{H}_{2} \mathrm{O}, \mathrm{NiCl}_{2} \cdot 6 \mathrm{H}_{2} \mathrm{O}, \mathrm{CuCl}_{2} \cdot 2 \mathrm{H}_{2} \mathrm{O}$ and $\mathrm{ZnCl}_{2}$ were purchased from Sigma-Aldrich company and used without further purification. The oxalic acid, hydrated hydrazine $99 \%$ and 1,2-phenylenediamine and solvents were supplied from Fluka company with $99 \%$ purity. 3-Acetyl coumarin was prepared according to the method assigned in literature [15].

Synthesis of 3-hydrazino-quinoxalin-2(1H)-one: This compound was prepared in two steps according to the reported method [16]. Yield: $88 \%$, m.p. $250-252^{\circ} \mathrm{C}, \mathrm{R}_{\mathrm{f}}=0.82$ (ethyl acetate:cyclohexane, v:v, 3:1). FT-IR $\left(\mathrm{KBr}, \mathrm{v}_{\max }, \mathrm{cm}^{-1}\right): 3400$ $\left(-\mathrm{NH}-\mathrm{NH}_{2}\right), 1683(\mathrm{C}=\mathrm{O}), 1588(-\mathrm{C}=\mathrm{N}), 2930-2855(-\mathrm{NH}-$ pyrazoline ring). ${ }^{1} \mathrm{H}$ NMR $\left(400 \mathrm{MHz}, \mathrm{DMSO}-d_{6}, \delta \mathrm{ppm}\right): 4.60$ (s, $2 \mathrm{H}, J=8.22 \mathrm{~Hz}, \mathrm{H}_{2} \mathrm{~N}-\mathrm{N}=\mathrm{C}-$ ), $7.22-7.59(\mathrm{~m}, 4 \mathrm{H}, J=6.33 \mathrm{~Hz}$, Ar-H), 8.90 (s, 1H, HN-N), 10.89 (s, $1 \mathrm{H}, J=6.35 \mathrm{~Hz}, \mathrm{HN}-\mathrm{C}=\mathrm{O}$ ), $12.22(\mathrm{~s}, 1 \mathrm{H}, J=4.90 \mathrm{~Hz}, \mathrm{HN}-\mathrm{C}=\mathrm{O})$. MS $(\mathrm{m} / \mathrm{z} \%): 176(100)$ $\left[\mathrm{M}^{+}\right]$.

Synthesis of $(E)$-3-[4-(2-hydroxybenzylidene)-3-methyl -5-oxo-4,5-dihydropyrazol-1-yl]-1H-quinoxalin-2-one: 2Hydrazinopyridine $(0.176 \mathrm{~g}, 10 \mathrm{mmol})$ in methanol $(15 \mathrm{~mL})$ was added to a solution of 3-acetylcoumarin $(1.88 \mathrm{~g}, 10 \mathrm{mmol})$ in methanol $(20 \mathrm{~mL})$ and the mixture was refluxed for $5 \mathrm{~h}$. The solid crude product formed was filtered off, dried in air and recrystallized from hot absolute ethanol as a deep yellow solid (Scheme-I). Yield: 0.247 g, $70 \%$; m.f. $\mathrm{C}_{19} \mathrm{H}_{14} \mathrm{~N}_{4} \mathrm{O}_{3}$; m.p. 200$202{ }^{\circ} \mathrm{C} ; \mathrm{R}_{\mathrm{f}}: 0.63$ (methanol:dichloromethane, v:v, 4:1). FT-IR $\left(\mathrm{KBr}, v_{\max }, \mathrm{cm}^{-1}\right): 3300(\mathrm{OH}), 1738(\mathrm{C}=\mathrm{O}), 1638,1610(\mathrm{C}=\mathrm{N})$, $1460(\mathrm{C}=\mathrm{C}) .{ }^{1} \mathrm{H}$ NMR $\left(400 \mathrm{MHz}, \mathrm{DMSO}-d_{6}, \delta \mathrm{ppm}\right): 2.5$ (s, $\left.3 \mathrm{H}, \mathrm{CH}_{3}\right), 6.5(\mathrm{t}, 1 \mathrm{H}, J=6.15 \mathrm{~Hz}, \mathrm{HC}=\mathrm{C}-), 6.99-7.22(\mathrm{~m}, 4 \mathrm{H}$, $J=3 \mathrm{~Hz}, \mathrm{Ar}-\mathrm{H}), 7.49-7.83$ (m, 4H, Ar-H), $9.86(\mathrm{~s}, 1 \mathrm{H}, J=$ $6.35 \mathrm{~Hz}, \mathrm{HO}-\mathrm{C}=\mathrm{C}), 10.22(\mathrm{~s}, 1 \mathrm{H}, J=5.33 \mathrm{~Hz}, \mathrm{HN}-\mathrm{C}=\mathrm{O}$ pyrazole). ${ }^{13} \mathrm{C}$ NMR (400 MHz, DMSO- $d_{6}, \delta$ ppm): 45.45, 75.18, 100.05,
$115.33,133.91,122.05,125.77,135.11,146.88,150.01,170.00$, 180.11, 198.10, 194.44, 196.65, 197.98. MS ( $\mathrm{m} / \mathrm{z} \%): 347$ (70) $\left[\mathrm{M}^{+}\right], 332$ (50) $\left[\mathrm{M}-\mathrm{CH}_{3}\right], 316(33)\left[\mathrm{M}-\mathrm{OH},-\mathrm{CH}_{3}\right]$.

Synthesis of metal complexes: A methanolic solution $(50 \mathrm{~mL})$ of corresponding metal(II) chloride e.g., [ $\mathrm{MnCl}_{2} \cdot 4 \mathrm{H}_{2} \mathrm{O}(0.221$ g), $\mathrm{CoCl}_{2} \cdot 6 \mathrm{H}_{2} \mathrm{O}(0.237 \mathrm{~g}), \mathrm{NiCl}_{2} \cdot 6 \mathrm{H}_{2} \mathrm{O}(0.237 \mathrm{~g}), \mathrm{CuCl}_{2} \cdot 2 \mathrm{H}_{2} \mathrm{O}$ $(0.170 \mathrm{~g})$ and $\left.\mathrm{ZnCl}_{2}(0.135 \mathrm{~g})\right]$ was added with constant stirring to ethanolic solution of ligand ( $1 \mathrm{mmol}, 0.347 \mathrm{~g}$ ) in $25 \mathrm{~mL}$ ethanol and refluxed on water bath for 3-5 h depending on the nature of metal ion. The obtained solid complex was separated by filtration under suction, washed with hot ethanol and dried in vacuum.

\section{RESULTS AND DISCUSSION}

All the metal complexes prepared are non-hygroscopic (stable at room temperature) and amorphous solids. These are soluble easily in DMSO, DMF and sparingly in ethanol and methanol whereas insoluble in chlorinated hydrocarbons. The elemental analyses data of the ligand and its metal complexes along with molar conductivity values are shown in Table-1. The molar conductance values of the complexes measured at room temperature in DMF solution with $0.001 \mathrm{~mol} / \mathrm{L}$ concentration fall in the range $18-30 \mathrm{ohm} . \mathrm{cm}^{2} / \mathrm{mol}$ indicating the non-electrolytic nature of the complexes [17] assigning to absence of chloride ions as counter ion in the structure of complexes. The formation of pyrazolinone ligand mainly proceeds by an attack of -NHgroup of intermediate formed up on condensation in the first step on carbonyl group (C-3 lactone), followed by ring closure to afford the pyrazole ring, which contains keto group that stabilizes the compound with inductive effect with neighboring benzopyrazine annulated ring [11,13] (Scheme-II).

IR studies: The key IR spectral bands of ligand and its corresponding metal complexes along with assignments are shown in Table-2.The absence of a band in the region 1710 $\mathrm{cm}^{-1}[15]$ which is characteristic of $\mathrm{H}_{3} \mathrm{C}-\mathrm{C}=\mathrm{O}$ group in chromone2-one derivative indicates the condensation with $\mathrm{H}_{2} \mathrm{~N}-\mathrm{NH}$ moiety of hydrazinoquinoxaline-2-one and give evidence to form imine $-\mathrm{C}=\mathrm{N}$ - group $[13,14]$. The strong absorptions at 1735 , 1590,1450 and $1650 \mathrm{~cm}^{-1}$ could be assigned to lactone $-\mathrm{C}=\mathrm{O},-\mathrm{N}=\mathrm{C}-$,<smiles>CC(=O)c1cc2ccccc2oc1=O</smiles>

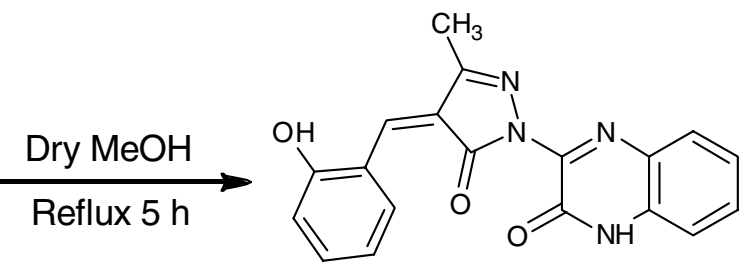

Scheme-I

TABLE-1

PHYSICO-CHEMICAL ANALYTICAL DATA OF SYNTHESIZED LIGAND AND ITS METAL(II) COMPLEXES

\begin{tabular}{|c|c|c|c|c|c|c|c|}
\hline \multirow{2}{*}{ Compound } & \multirow{2}{*}{ m.w. $(\mathrm{g} / \mathrm{mol})$} & \multirow{2}{*}{ Colour } & \multirow{2}{*}{ m.p. $\left({ }^{\circ} \mathrm{C}\right)^{\mathrm{a}}$} & \multicolumn{4}{|c|}{ Elemental analysis (\%): Calcd. (found) } \\
\hline & & & & $\mathrm{C}$ & $\mathrm{H}$ & $\mathrm{N}$ & $M^{\mathrm{b}}$ \\
\hline $\mathrm{L}$ & 347.05 & Pale yellow & $200-202$ & $65.98(65.33)$ & $4.09(3.55)$ & $16.20(15.88)$ & - \\
\hline$\left[\mathrm{MnLCl}_{2}\right]$ & 472.25 & Reddish brown & 300-302 (Dec.) & $48.86(46.99)$ & $4.00(3.99)$ & $13.11(13.59)$ & $12.22(11.53)$ \\
\hline$\left[\mathrm{CoLCl}_{2}\right] \cdot \mathrm{H}_{2} \mathrm{O}$ & 493.80 & Brown & 305-307 (Dec.) & $47.90(46.93)$ & $3.39(2.88)$ & $14.55(15.00)$ & $12.88(12.11)$ \\
\hline$\left[\mathrm{NiLCl}_{2}\right] \cdot \mathrm{H}_{2} \mathrm{O}$ & 495.11 & Orange & 310-312 (Dec.) & $46.99(46.81)$ & $3.00(2.90)$ & $12.00(12.81)$ & $12.34(12.66)$ \\
\hline$\left[\mathrm{CuLCl}_{2}\right] \cdot 2 \mathrm{H}_{2} \mathrm{O}$ & 515.00 & Beige & 290-292 (Dec.) & $47.20(46.05)$ & $2.95(2.49)$ & $12.00(12.22)$ & $13.30(13.00)$ \\
\hline$\left[\mathrm{ZnLCl}_{2}\right]$ & 480.00 & White off & $278-280$ (Dec.) & $46.05(45.95)$ & $2.66(2.09)$ & $11.44(11.80)$ & $15.09(14.76)$ \\
\hline
\end{tabular}

${ }^{\mathrm{a}}$ Dec: Decomposed, ${ }^{\mathrm{b}}$ Content of metal was estimated by flame atomic absorption spectroscopy. 


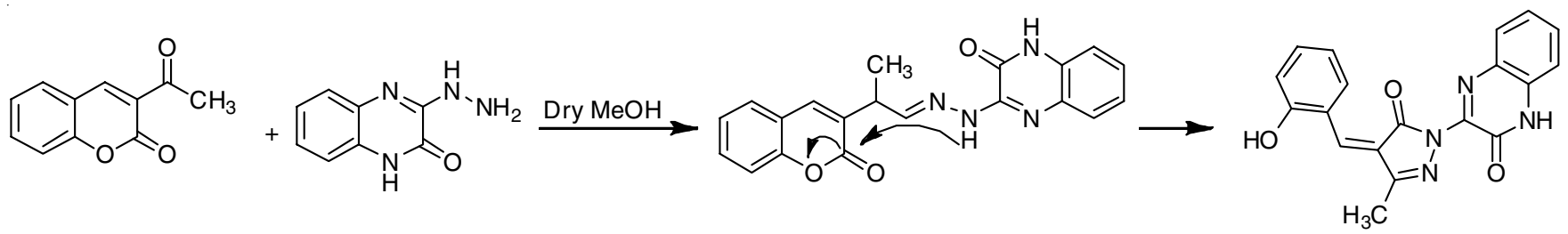

Scheme-II: Proposed steps wise of ligand formation

\begin{tabular}{|c|c|c|c|c|c|c|c|c|}
\hline \multicolumn{9}{|c|}{$\begin{array}{c}\text { TABLE-2 } \\
\text { FT-IR KEY ABSORPTIONS OF LIGAND AND ITS METAL COMPLEXES }\left(\mathrm{cm}^{-1}\right)\end{array}$} \\
\hline Compound & $v(\mathrm{NH})$ & $v(\mathrm{C}=\mathrm{O})$ & $v(\mathrm{C}=\mathrm{N})$ & $v(\mathrm{C}-\mathrm{H})$ & $v(\mathrm{C}-\mathrm{N})$ & $v(\mathrm{M}-\mathrm{N})$ & $v(\mathrm{M}-\mathrm{O})$ & $v(\mathrm{M}-\mathrm{Cl})$ \\
\hline $\mathrm{QHZ}$ & $3350(\mathrm{~m})$ & $1680(s)$ & $1610,1590(\mathrm{~s})$ & $3010(w)$ & $1420(\mathrm{~m})$ & - & - & - \\
\hline Ligand & 3380 & $1735,1650(\mathrm{~s})$ & $1630(\mathrm{sh})$ & $3090(w), 2970(\mathrm{~m})$ & $1433(\mathrm{~m})$ & - & - & - \\
\hline$\left[\mathrm{MnLCl}_{2}\right]$ & 3180 & 1740,1640 & $1610(\mathrm{~s})$ & $3050(w), 2964(\mathrm{~m})$ & $1410(\mathrm{~s})$ & $520(\mathrm{~m})$ & $436(\mathrm{~m})$ & $355(w)$ \\
\hline$\left[\mathrm{CoLCl}_{2}\right] \cdot \mathrm{H}_{2} \mathrm{O}$ & 3300 & 1733(s), 1642(sh) & $1560(\mathrm{~s})$ & $3010(w), 2987(\mathrm{~m})$ & $1433(\mathrm{~s})$ & $530(w)$ & $430(\mathrm{~m})$ & $380(w)$ \\
\hline$\left[\mathrm{NiLCl}_{2}\right] \cdot \mathrm{H}_{2} \mathrm{O}$ & 3235 & $1738,1641(\mathrm{sh})$ & $1570(\mathrm{~s})$ & $3010(w), 2967(\mathrm{~m})$ & $1390(\mathrm{~s})$ & $522(w)$ & $477(\mathrm{~m})$ & $370(w)$ \\
\hline$\left[\mathrm{CuLCl}_{2}\right] \cdot 2 \mathrm{H}_{2} \mathrm{O}$ & 3369 (br) & $1735(\mathrm{~s}), 1640(\mathrm{~s})$ & $1585(\mathrm{~s})$ & $3010(\mathrm{~m}), 2977(\mathrm{~m})$ & 1398(m) & $500(w)$ & $480(\mathrm{~m})$ & $390(w)$ \\
\hline$\left[\mathrm{ZnLCl}_{2}\right]$ & 3300 & $1739(\mathrm{~s}), 1642(\mathrm{sh})$ & 1575 (s) & $3010(w), 3000(w)$ & $1422(\mathrm{~m})$ & $515(w)$ & $450(w)$ & 359 (w) \\
\hline
\end{tabular}

$\mathrm{C}-\mathrm{N}$ and $-\mathrm{C}=\mathrm{O}$ of pyranopyrazole [16]. The absorption of $v(\mathrm{NH})$ related to quinoxaline ring and hydrazine $v\left(\mathrm{NH}_{2}\right)$ were observed around $2955-2855 \mathrm{~cm}^{-1}$ for pyrazine ring $-\mathrm{NH}$ - as broad band was disappeared by reaction of hydrazine group - HN$\mathrm{NH}_{2}$ with acetyl group of coumarin thus indicates the formation of pyrazole ring [13]. However, the appearance of strong absorption in the free ligand at $1020-950 \mathrm{~cm}^{-1}$ reveals the pyrazole based ligand. In the complexes, it is remarkable shifts to lower frequency region $\left(1645-1640 \mathrm{~cm}^{-1}\right)$ and $\left(1610-1560 \mathrm{~cm}^{-1}\right)$ due to the formation of $\mathrm{M}-\mathrm{O}$ and $\mathrm{M}-\mathrm{N}$ bonds since the drift of lone pairs on oxygen and nitrogen atoms moved to vacant orbitals of the metal ions [18]. In the spectra of all the metal complexes, a weak bands were appeared in the far-infrared regions 390$355 \mathrm{~cm}^{-1}$, this may be attributed to $\mathrm{M}-\mathrm{Cl}$ bonds and support the participation of chloride ions in inner sphere of metal complexes structures $[15,16]$. The bands due to $\mathrm{v}(\mathrm{NH})$ are broadened in all the complexes due to the overlapping of $v(\mathrm{OH})$ bands of enol form of ligand to $\mathrm{H}-\mathrm{N}$-of pyrazoline ring. The non-ligand bands in the region 530-500 and 480-430 $\mathrm{cm}^{-1}$ were assigned to $v(\mathrm{M}-\mathrm{N})$ and $v(\mathrm{M}-\mathrm{O})$, respectively $[16,17]$.

${ }^{1} \mathbf{H}$ and ${ }^{13} \mathbf{C}$ NMR studies: The ligand displays two sharp singlet at $\delta 11.70 \mathrm{ppm}$ attributed to the resonance of deshielded protons of pyrazine ring $\mathrm{NH}-\mathrm{C}=\mathrm{O}$. As well as the proton of $-\mathrm{OH}$ group attached to phenyl group that mainly belonged to coumarin derivative was appeared at $\delta 9.11 \mathrm{ppm}$, which support the ring closure occurred by attaching of lone pair of - $\mathrm{NH}$ - on the carbon atom C-O of lacton moiety [17]. However, the absorption of aliphatic $-\mathrm{CH}_{3}$ was observed in the region $3.88 \mathrm{ppm}$ as singlet peak which is strong evidence for the keto-enol forms of the free ligand in solution. The nuclear resonance of aromatic protons $\mathrm{Ar}-\mathrm{H}$ and pyrazine $\mathrm{H}$ were recorded about (6.90-7.11) and (7.90-8.22) ppm, respectively. Furthermore, ${ }^{13} \mathrm{C}$ NMR showed distinct absorptions of $-\mathrm{C}=\mathrm{N}-$ at 190 and $220 \mathrm{ppm}$ indicating the ring closure of pyrazolinone ring $[12,13]$. However, the other peaks belonged to aromatic $-\mathrm{C}=\mathrm{C}$ - of pyrazine and phenyl rings were measured around (88.2-137) $\mathrm{ppm}$. The aliphatic $-\mathrm{CH}_{3}$ was resonated at $38.70 \mathrm{ppm}$ indicating the effect of withdrawing groups and resonance effect on the positions of the functional groups in the ligand $[15,16]$.
Mass spectral studies: The mass spectra of starting materials, 3-hydrazinoquinoxaline-2-one, 3-acetylcoumarin and free ligand with its metal complexes with $\mathrm{Co}(\mathrm{II})$ and $\mathrm{Cu}(\mathrm{II})$ were carried out in order to elucidate the proposed structure of complexes. The molecular ion at $\mathrm{M}^{+}=188$ of $100 \%$ intensity support the proposed formula of 3-acetylcumarine $\mathrm{C}_{11} \mathrm{H}_{8} \mathrm{O}_{3}{ }^{+}$whereas the molecular ion $\mathrm{M}+1$ at 176, supporting the proper formula of 3-hydrazino-quinoxaline-2-one. The EIMS spectrum of the free ligand (LH) exhibits the nuclear resonance of molecular ion related to free pyrazoline-quinoxaline based ligand which is remarkably observed from the base peak at $\mathrm{M}^{+}=347$ gives strong evidence for ring closure of Schiff base intermediate, formed via condensation of acetyl moiety of coumarin with 2-hydrazinoquinoxaline. The mass spectra of cobalt(II) complex displayed absorptions around $m / e=474$ and 442 due to molecular ions of $\mathrm{MnLCl}_{2}{ }^{+}$and $\mathrm{MnLCl}^{+}$, respectively confirming the isotope effect of manganese(II). As shown in Fig. 1, the cleavages of - $\mathrm{Cl}$ and -OH in addition to substraction of hydrated water molecules confirm the right suggested molecular structure of the prepared complex. In the same way, the low intensity peak at 477 in the mass spectrum of zinc(II) complex (Fig. 2) may be associated with the molecular ion $\left[\mathrm{ZnCl}_{2}\right]^{+}$whereas the fragmentations at 436, 298 and 167 are belonged to the
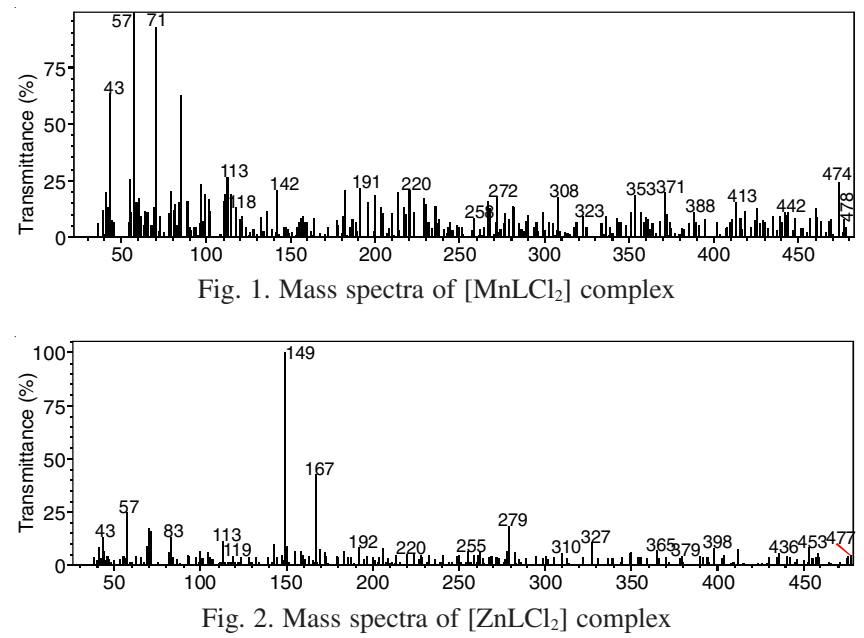
TABLE-3

ELECTRONIC SPECTRA, MOLAR CONDUCTANCE AND THE MAGNETIC MOMENTS OF SYNTHESIZED LIGAND AND ITS METAL(II) COMPLEXES

\begin{tabular}{ccccc}
\hline Compound & UV-visible $\left(\lambda_{\max }\right)$ & $\mu(\mathrm{BM})$ & $\Lambda_{\mathrm{m}}\left(\mathrm{S} \mathrm{mol}^{-1} \mathrm{~cm}^{2}\right)^{*}$ & - \\
\hline Ligand $(\mathrm{L})$ & 260,360 & - & - & - \\
{$\left[\mathrm{MnLCl}_{2}\right]$} & 340,455 & 5.80 & 20 & Tetrahedral \\
{$\left[\mathrm{CoLCl}_{2}\right] \cdot \mathrm{H}_{2} \mathrm{O}$} & $370,690,875$ & 3.90 & Tetrahedral \\
{$\left[\mathrm{NiLCl}_{2}\right] \cdot \mathrm{H}_{2} \mathrm{O}$} & $378,600,744$ & 3.04 & 30 & Tetrahedral \\
{$\left[\mathrm{CuLCl}_{2}\right] \cdot 2 \mathrm{H}_{2} \mathrm{O}$} & 333,690 & 1.70 & 22 & Tetrahedral \\
{$\left[\mathrm{ZnLCl}_{2}\right]$} & 280,390 & 0 & 25 & Tetrahedral \\
\hline$* \Lambda_{\mathrm{m}}=$ molar conductance was measured in DMF solutions, $\mu=$ magnetic moment in Bohr Magneton unit.
\end{tabular}

breaking of weak points of methyl and hydroxyl groups in the organic moiety of pyrazolinone ring $[18,19]$.

Electronic spectra and magnetic properties: The electronic absorptions of the ligand and its metal complexes solutions in DMF and ethanol are shown in Table-3. The solution of ligand in ethanol displays two spin-allowed transitions in the regions 260 and $360 \mathrm{~nm}$ which is characteristic of $-\mathrm{C}=\mathrm{N}-,-\mathrm{C}=\mathrm{C}$ - and $-\mathrm{C}=\mathrm{O}$ functional groups incorporated in pyrazole and pyrazine rings, respectively $[12,15]$. The pale coloured solution of $\mathrm{Mn}$ (II) complex showed weak peak at $455 \mathrm{~nm}$ and other of high intensity at $340 \mathrm{~nm}$, these may be assigned to $d$ - $d$ and MLCT, respectively $[13,20]$. The cobalt(II) complex exhibited spin-allowed $d-d$ transitions at 870 and $690 \mathrm{~nm}$ that are assigned to ${ }^{4} \mathrm{~A}_{2} \rightarrow$ ${ }^{4} \mathrm{~T}_{1}(\mathrm{P})$ and ${ }^{4} \mathrm{~A}_{2} \rightarrow{ }^{4} \mathrm{~T}_{1}(\mathrm{~F})$, respectively, which is typical for tetrahedral $\mathrm{Co}$ (II) complexes [21]. At the same way, the electronic spectra of nickel(II) complex in DMF at 730 and $550 \mathrm{~nm}$ are assigned to ${ }^{3} \mathrm{~T}_{1}(\mathrm{~F}) \rightarrow{ }^{3} \mathrm{~T}_{1}(\mathrm{P})$ and ${ }^{3} \mathrm{~T}_{1}(\mathrm{~F}) \rightarrow{ }^{3} \mathrm{~A}_{1}(\mathrm{~F})$, respectively [22] thus ascribing the tetrahedral structure around $\mathrm{Ni}$ (II) ion. Due to the distorted tetrahedral configuration, $\mathrm{Cu}$ (II) complex showed a broad band at $690 \mathrm{~nm}$ for ${ }^{2} \mathrm{~T}_{2} \rightarrow 2 \mathrm{E}$ transition supporting the distorted tetrahedral geometry. The values of magnetic moments for solid complexes displayed increasing for cobalt and nickel(II) complexes due to orbital contribution and high spin state for tetrahedral symmetry $[16,18,22]$. The magnetic susceptibility measurements thus help to predict the possible geometry of the metal complexes. In paramagnetic Mn(II), $\mathrm{Co}(\mathrm{II})$ and $\mathrm{Cu}(\mathrm{II})$ complexes, often the magnetic moment $\left(\mu_{\mathrm{eff}}\right)$ gives the spin value corresponding to the number of unpaired electron, while tetrahedral nickel(II) complex showed little increasing in magnetic moment due to spin-orbital coupling effect [23]. The expected magnetic values of $\mathrm{Cu}$ (II) and $\mathrm{Mn}$ (II) complexes are 1.77 and 5.80 B.M., respectively [23,24]. Thus the value of magnetic moment of a complex would give valuable insights into its constitution and structure. The magnetic susceptibility measurements obtained at room temperature for $\mathrm{Ni}$ (II) complex can be associated with its configurations, stereochemistry, hybrid orbital and number of unpaired electrons, spinonly and expected magnetic values at 3.04 B.M.

\section{Conclusion}

The synthesis of (E)-3-[4-(2-hydroxybenzylidene)-3-methyl5-oxo-4,5-dihydropyrazol-1-yl]-1H-quinoxalin-2-one was done by ring closure of of 3-acetyl-coumarin with 2-hydrazinoquinoxaline-2-one in an equimolar ratio in dry methanol. The geometry of newly synthesized compounds were elucidated based on their elemental analysis, magnetic susceptibility measurements and spectral data. The stoichiometry of free ligand and its metal complexes were confirmed by elemental analyses.
The metal/ligand ratio was found to be 1:1 estimated by determining the metal and ligand content of the metal complexes. The data obtained from IR spectra suggested the participation of carbonyl and imine moiety of pyrazoline and pyrazine rings with the metal ions. According to the molar conductance, magnetic susceptibility and spectral data, the tetrahedral geometry of the prepared complexes is shown in Scheme-III. However, the interesting work of pyrazolinone complexes may have led to novel work in future that would enclose thermal analysis and antimicrobial studies.
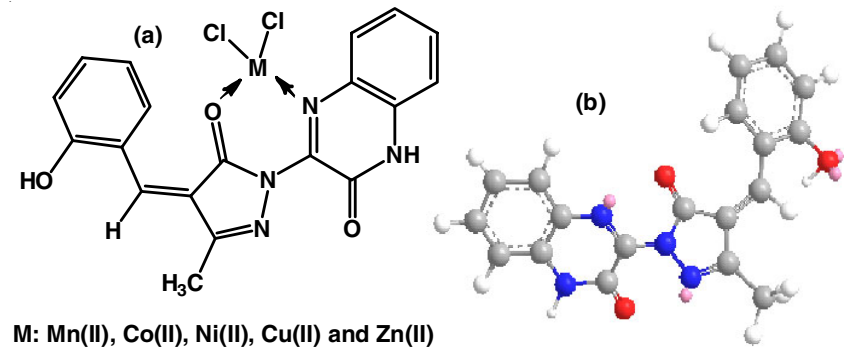

$\mathrm{M}: \mathrm{Mn}(\mathrm{II}), \mathrm{Co}(\mathrm{II}), \mathrm{Ni}(\mathrm{II}), \mathrm{Cu}(\mathrm{II})$ and $\mathrm{Zn}$ (II)

Scheme-III: The tentative structure of the complexes (a) and 3D structure of ligand (b)

\section{ACKNOWLEDGEMENTS}

The authors thank Department of Chemistry, College of Science, University of Mustansiriyah, Baghdad, Iraq for providing spectral and analytical facility. Recording of magnetic susceptibility and elemental analyses are also gratefully acknowledged. Thanks are also due to Al-Yarmook University (Jordan) for facilitating the NMR analyses.

\section{CONFLICT OF INTEREST}

The authors declare that no conflict of interest regarding the publishing of the article.

\section{REFERENCES}

1. X.-H. Lv, Q.-S. Li, Z.-L. Ren, M.-J. Chu, J. Sun, X. Zhang, M. Xing, H.-L. Zhu and H.-Q. Cao, Eur. J. Med. Chem., 108, 586 (2016); https://doi.org/10.1016/j.ejmech.2015.12.020.

2. S. Kumar, S. Bawa, S. Drabu, R. Kumar and H. Gupta, Recent Pat. Antiinfect. Drug Discov., 4, 154 (2009). https://doi.org/10.2174/157489109789318569.

3. S. Mert, R. Kasimogullari, T. Iça, F. Çolak, A. Altun and S. Ok, Eur. J. Med. Chem., 78, 86 (2014); https://doi.org/10.1016/j.ejmech.2014.03.033.

4. T.F.S. Silva, T.C.O.M. Leod, L.M.D.R.S. Martins, M.F.C. Guedes da Silva, M.A. Schiavon and A.J.L. Pombeiro, J. Mol. Catal. Chem., 367, 52 (2013); https://doi.org/10.1016/j.molcata.2012.10.024. 
5. E. Budzisz, M. Miernicka, I.-P. Lorenz, P. Mayer, E. Balcerczak, U. Krajewska and M. Rozalski, Eur. J. Med. Chem., 45, 2613 (2010); https://doi.org/10.1016/j.ejmech.2010.02.050.

6. V. Montoya, J. Pons, X. Solans, M. Font-bardia and J. Ros, Inorg. Chim. Acta, 358, 2312 (2005); https://doi.org/10.1016/j.ica.2004.12.060.

7. A.S. Abu-Surrah, T.A.K. Al-Allaf, L.J. Rashan, M. Klinga and M. Leskelä, Eur. J. Med. Chem., 37, 919 (2002); https://doi.org/10.1016/S0223-5234(02)01415-0.

8. A. Salzer, Coord. Chem. Rev., 242, 59 (2003); https://doi.org/10.1016/S0010-8545(03)00059-6.

9. H. Maruoka, S. Nishida, N. Kashige, Y. Yoshimura, M. Omori, R. Tomita, E. Masumoto, F. Okabe, F. Miake, K. Yamagata and T. Fujioka, J. Heterocycl. Chem., 49, 1218 (2012); https://doi.org/10.1002/jhet.919.

10 K. Sundaravel, E. Suresh and M. Palaniandavar, Inorg. Chim. Acta, 363, 2768 (2010); https://doi.org/10.1016/j.ica.2010.04.025.

11. S. Budagumpi, U.N. Shetti, N.V. Kulkarni and V.K. Revankar, J. Coord. Chem., 62, 3961 (2009); https://doi.org/10.1080/00958970903261317.

12. C.J. Dhanaraj and J. Johnson, Appl. Organomet. Chem., 30, 860 (2016); https://doi.org/10.1002/aoc.3514.

13. D.S. Rani and V.J. Raju, Indian J. Chem., 38A, 385 (1999).

14. M.M. Abdou, R.A. El-Saeed and S. Bondock, Arab. J. Chem.; https://doi.org/10.1016/j.arabjc.2015.06.029.
15. M.A. Gouda, M.A. Berghot, E.A. Baz and W.S. Hamama, Med. Chem. Res., 21, 1062 (2012); https://doi.org/10.1007/s00044-011-9610-8.

16. P.V. Anantha Lakshmi, P.S. Reddy and V.J. Raju, Spectrochimica Acta Part A, 74, 52 (2009); https://doi.org/10.1016/j.saa.2009.05.007.

17. E.K. Efthimiadou, G. Psomas, Y. Sanakis, N. Katsaros and A. Karaliota, J. Inorg. Biochem., 101, 525 (2007); https://doi.org/10.1016/j.jinorgbio.2006.11.020.

18. K. Nakamato, Infrared and Raman Spectra of Inorganic and Coordination Copounds, John Wiley \& Sons, New York, edn 5, pp. 183-187 (1998).

19. D.W. Mayo, F.A. Miller and R.W. Hannah, Course Notes on the Interpretation of Infrared and Raman Spectra, John Wiley \& Sons, Hoboken: USA (2003).

20. A.B.P. Lever, Inorganic Electronic Spectroscopy, Elsevier Publishing Company: New York (1968)

21. J.E. Huheey, Inorganic Chemistry, Principles of Structure and Reactivity Harper International: Maryland, USA, edn 51 (1994).

22. J.C. Bailar, H.J. Emeleus, S.R. Nyholm and A.F. Dickenson, Comprehensive Inorganic Chemistry, Pergamon Press, New York (1975).

23. A.S. El-Tabl, F.A. Aly, M.M.E. Shakdofa and A.M.E. Shakdofa, $J$. Coord. Chem., 63, 700 (2010); https://doi.org/10.1080/00958970903545099.

24. K. Nakamoto and P.J. McCarthy, Spectroscopy and Structure of Metal Chelate Compounds, John Wiley \& Sons, New York (1968). 